\title{
A DESCONSIDERAÇÃO DA PERSONALIDADE JURÍDICA SOB A ÓTICA DA ANÁLISE ECONÔMICA DO DIREITO
}

\author{
THE DISREGARD OF LEGAL ENTITY UNDER THE OPTICS OF THE ECONOMIC \\ ANALYSIS OF LAW
}

\author{
PENETRACIÓN DE LA PERSONALIDAD JURÍDICA BAJO LA ÓPTICA DEL \\ ANÁLISIS ECONÓMICO DEL DERECHO
}

\author{
ANA LÚCIA BARELLA \\ https://orcid.org/0000-0002-6307-2402 / http://lattes.cnpq.br/7149044491966282 / alb.curitiba@gmail.com \\ Centro Universitário Curitiba - UNICURITIBA \\ Curitiba, PR, Brasil.
}

\begin{abstract}
SANDRO MANSUR GIBRAN
https://orcid.org/0000-0003-2738-7199 / http://lattes.cnpq.br/3242304285536069 / sandro@rochaadvogados.com Centro Universitário Curitiba - UNICURITIBA Curitiba, PR, Brasil.
\end{abstract}

\begin{abstract}
RESUMO
Pautada pelo método dedutivo, a pesquisa observará, inicialmente, a Análise Econômica do Direito, em seguida, o instituto da Desconsideração da Personalidade Jurídica e, por fim, a relação entre ambos pela aplicação do método ao direito material, de modo que sirvam os primeiros como premissas na dedução da relação. Referências bibliográficas diversas serviram como base na análise de cada uma, com o objetivo de possibilitar a aplicação dos métodos da Análise Econômica do Direito às bases materiais da Desconsideração da Personalidade Jurídica. Os estudos revelaram que a Teoria Maior é eficiente, ao passo que a Teoria Menor é ineficiente por aumentar os custos a que os sócios estão sujeitos na atuação da Personalidade Jurídica.
\end{abstract}

Palavras-chave: Análise Econômica do Direito; Código de Processo Civil; Desconsideração da Personalidade Jurídica; Direito Econômico.

\section{ABSTRACT}

Guided by the deductive method, the research will initially observe the Economic Analysis of Law, then the Institute of Disregard for Legal Entity and, finally, the relation between both by applying the method to the material law, so that they serve the first as assumptions in the deduction of the relationship. Various bibliographic references served as a basis for the analysis of each one, with the objective of enabling the application of the methods of Economic Analysis of the Right to the material bases of Disregard of Legal Entity. The studies revealed that the Major Theory is efficient, whereas the Minor Theory is inefficient for increasing the costs to which the members are subject in the performance of the Legal Personality.

Keywords: Law and Economics; Civil Procedure Code; Disregard of Legal Entity; Economics Law.

\section{RESUMEN}

Guiada por el método deductivo, la investigación observará inicialmente el Análisis Económico de la Ley, luego el Instituto de Penetración de la Personalidad Jurídica y, finalmente, la relación entre ambos aplicando el método a la ley material, para que sirvan al primero como premisas en la deducción de la relación. Varias referencias bibliográficas sirvieron de base para el análisis de cada una, con el fin de permitir la aplicación de los métodos de Análisis Económico del Derecho a las bases materiales de la Penetración de la Personalidad Jurídica. Los estudios han demostrado que la Teoría Mayor es eficiente, mientras que la Teoría Menor es ineficiente porque aumenta los costos a los que los socios están sujetos en el desempeño de la Personalidad Jurídica. 
Palabras-clave: Análisis Económico del Derecho; Codigo de Proceso Civil; Penetración de la Personalidad Jurídica; Derecho Económico.

\section{SUMÁRIO}

INTRODUÇÃO, 1 ANÁLISE ECONÔMICA DO DIREITO, 2 DESCONSIDERAÇÃO DA PERSONALIDADE JURÍDICA, 3 A DESCONSIDERAÇÃO DA PERSONALIDADE JURÍDICA SOB A ÓTICA DA ANÁLISE ECONÔMICA DO DIREITO, CONCLUSÃO, REFERÊNCIAS.

\section{INTRODUÇÃO}

A Desconsideração da Personalidade Jurídica é instituto cuja aplicação remonta aos anos de 1970 no Brasil. Apenas em 1990, com o Código de Defesa do Consumidor (CDC), surgiu a primeira norma material sobre o assunto. No entanto, a ausência de norma não impediu o judiciário de desconsiderar as Pessoas Jurídicas e atingir o patrimônio de sócios que se utilizavam da sociedade para cometer abusos. Mas foi em 2002, com o Código Civil (CC), que esse instituto recebeu critérios para sua aplicação.

A partir das diferenças entre 0 art. $28, \$ 5^{\circ}$ do CDC e o art. 50 do CC surgiram teorias sobre a Desconsideração da Personalidade Jurídica (DPJ), a Teoria Maior e a Teoria Menor. A primeira considera indispensáveis os critérios do art. 50 do CC para desconsiderar uma Pessoa Jurídica (PJ); enquanto a segunda está pautada no CDC e estabelece que a PJ será desconsiderada se for obstáculo ao pagamento dos débitos ao credor.

Essa diferença na aplicação do instituto foi objeto da presente pesquisa porque as consequências da utilização de cada uma dessas teorias são diversas e interferem na eficiência das normas materiais que embasam tal aplicação.

Um método que permite avaliar a eficiência de normas é a Análise Econômica do Direito (AED), que tem como base a análise conjunta sob a ótica do Direito associado à Economia. Para a AED, as normas são incentivos que devem considerar exterioridades nas ações dos indivíduos e pretendem tornar a alocação de recursos mais eficiente; pauta-se na melhor maneira de atingir o bem-estar social da comunidade estudada, situação considerada como de maior eficiência.

Tal análise acontece por meio da observação e contextualização das normas vigentes; da análise da aplicação da legislação envolvida, dos incentivos e da diminuição dos custos que pretende alcançar; da formulação de hipóteses que tornem mais eficiente a ação do públicoalvo; da conclusão acerca da eficiência das normas vigentes ou de sua ausência; e da proposta de novos incentivos pela alteração do sistema analisado. 
Assim, o objetivo da pesquisa é analisar, inicialmente, as premissas da Análise Econômica do Direito e do instituto da Desconsideração da Personalidade Jurídica a partir de fontes bibliográficas diversas relativas ao tema para, pelo método dedutivo, aplicando-se o método da Análise Econômica do Direito à Desconsideração da Personalidade Jurídica, seguindo as etapas possíveis de serem utilizadas numa pesquisa jurídico-doutrinária, concluir pela eficiência ou não das normas de direito material e suas respectivas teorias, que servem como base para ignorar-se a Pessoa Jurídica que protege seus sócios.

A partir aplicação da Análise Econômica do Direito às teorias da Desconsideração da Personalidade Jurídica foi possível concluir que a Teoria Maior da desconsideração é eficiente economicamente, ao contrário da Teoria Menor, que, ao aumentar os custos a todos os sócios, torna-se ineficiente economicamente, não atingindo os objetivos propostos pela norma.

\section{ANÁLISE ECONÔMICA DO DIREITO}

A Análise Econômica do Direito (AED) teve suas origens na Escola de Chicago a partir da edição de uma revista chamada Journal of Law and Economics dirigida por Aaron Director, em 1937 que, logo depois, passou a ser dirigida por Ronald Coase. Essa revista "se tornará o veículo para difundir as incursões dos economistas na área do direito. 0 ponto de partida é o artigo de Ronald Coase sobre o custo social, publicado em 1960, que lhe valeu o prêmio Nobel em 1991"1.

Até 1960 a teoria era voltada ao estudo do direito da concorrência por meio da AntTrust-Law, nos Estados Unidos. No Brasil, a AED passou a ser estudada por volta de 1990, quando alguns cursos de mestrado e doutorado passaram a incluí-la em seus programas.

Para Mackaay e Rousseau, a obra "que vai dominar o movimento ao longo dos dez anos seguintes"2, foi publicada por Richard A. Posner, professor de direito, no livro Economic Analysis of Law.

Após o desastre do positivismo utilizado pelos nazistas na Segunda Grande Guerra, a reação do universo jurídico foi no sentido de impedir que erros de interpretação voltassem a ocorrer.

A Escola Realista Americana tentou solucionar o problema com a Análise Econômica do Direito, aproximando o Direito da realidade social pelas ciências. Já no Brasil o caminho

\footnotetext{
1 MACKAAY, Ejan; ROUSSEAU, Stéphane. Análise Econômica do Direito. trad. Rachel Sztajn. 2.ed. São Paulo: Atlas, 2015. p. 9.

${ }^{2}$ MACKAAY, Ejan; ROUSSEAU, Stéphane. Análise Econômica do Direito. trad. Rachel Sztajn. 2.ed. São Paulo: Atlas, 2015. p. 11.
} 
encontrado foi o neoconstitucionalismo, pretendendo reaproximar o Direito da filosofia, por meio da relativização das decisões judiciais.

A AED é fruto, assim, da juseconomia, onde o direito é entendido como um conjunto de regras que estabelece custos e benefícios a seus agentes, tendo como base diagnósticos de como o agente comporta-se diante de uma regra jurídica e de que forma a mudança dessa regra alteraria seu comportamento.

Segundo Ivo T. Gico Júnior, a Análise Econômica do Direito é “um método de investigação aplicado ao problema, método econômico, cujo objetivo pode ser qualquer questão que envolva escolhas humanas" . Ainda, "é a utilização da abordagem econômica para tentar compreender o direito no mundo e o mundo do direito" ${ }^{4}$, de acordo com o autor. Ou seja, para Gico Júnior a AED diz respeito aos "meios que as pessoas usam para alcançar seus fins, não sobre os fins que buscam" 5 .

Pode-se considerar que a Análise Econômica do Direito não avalia o objetivo final do comportamento, mas o modo como esse objetivo é alcançado. Nesse sentido, é possível distinguir dois focos para a AED: uma AED positiva e outra normativa. A primeira trata do que é a norma, sua racionalidade e consequências, do fato, do ser; enquanto a segunda volta-se ao dever-ser, auxilia a escolher, dentre as alternativas, a mais eficiente ${ }^{6}$.

A medida de valor nessa análise é a “fórmula do bem-estar social”, entendida por Porto como "agregação dos níveis de utilidade de todos os indivíduos de uma sociedade por somatório simples"7. Tem como condição um mercado perfeito, onde existem produtos para todos, mesmo que se mantenha a escassez geral; onde existem tomadores de preços, ou seja, compradores que podem negociar os preços, estando todos em igualdade para tanto; onde o fluxo de informações é perfeito, quando as informações acerca do negócio, de seus riscos e benefícios são claros e conhecidos pelos agentes; onde há liberdade para negociar ou não, isto é, os agentes têm a liberdade para entrar e sair do mercado sempre que entenderem conveniente, sem que exista qualquer obrigação de assim fazê-lo.

${ }^{3}$ GICO JR., Ivo T.. Introdução à Análise Econômica do Direito. In: RIBEIRO, Márcia Carla Pereira; KLEIN, Vinícius (Coord.) 0 que é análise econômica do direito: uma introdução. Belo Horizonte: Fórum, 2011. p. 19.

${ }^{4}$ GICO JR., Ivo T.. Introdução à Análise Econômica do Direito. In: RIBEIRO, Márcia Carla Pereira; KLEIN, Vinícius (Coord.) $O$ que é análise econômica do direito: uma introdução. Belo Horizonte: Fórum, 2011. p. 20.

${ }^{5}$ GICO JR., Ivo T.. Introdução ao Direito e Econômica. In: TIMM, Luciano Benetti (Org.) Direito e Economia no Brasil. São Paulo: Atlas, 2014. p. 25

${ }^{6}$ GICO JR, 2011. p. 20-1.

7 PORTO, Antônio José Maristrello. Análise Econômica do Direito (AED). Rio de Janeiro: Fundação Getúlio Vargas, 2013. p. 15. 
Esse mercado perfeito diz respeito aos próprios pressupostos de existência da Análise Econômica do Direito, quais sejam:

a) escassez de recursos - não seria necessária qualquer análise se existissem tantos produtos quanto o necessário para atender a todos que os desejassem; assim, a procura pela eficiência na alocação dos recursos está ligada ao fato de que os recursos são escassos e sua utilização precisa ser eficiente;

b) custos de oportunidade - dizem respeito ao fato de que qualquer negociação demanda custos, sejam os de busca por fornecedores/ compradores, os inerentes à negociação em si, ou os custos com a manutenção do contrato e os incentivos que provoquem sua execução;

c) conduta racional maximizadora - a AED pressupõe que os agentes farão escolhas racionais de maneira a alocar da forma mais eficiente possível os recursos que detêm;

d) ponderação entre custos e benefício - respostas aos incentivos oferecidos para realização, manutenção e execução dos contratos;

e) contexto em que o agente está inserido - podem ser de duas ordens: hierárquico ou mercadológico. 0 primeiro diz respeito às relações em que uma das partes impõe a outra a tomada de certas decisões, às relações em que não há simetria entre os agentes. Já o contexto mercadológico está relacionado justamente a um ambiente de igualdade entre as partes, em que uma não tem o poder de determinar a decisão da outra; importante ressaltar que o termo mercadológico está ligado a essa equidade na tomada de decisão e não tem relação direta com o que se entende por mercadológico no âmbito das trocas econômicas, de consumo, por exemplo;

f) individualismo metodológico - a AED analisa as decisões de cada agente individualmente e considera o social como a somatória dessas decisões, por isso seu método é considerado individualista;

g) modelos teóricos - para que os problemas sejam estudados, a AED utiliza-se de modelos teóricos dos problemas que deseja investigar, realizando um diagnóstico do comportamento frente aos problemas atuais e projetando modelos que analisem a alteração dos comportamentos diante da mudança das regras, de novos incentivos aos jogadores;

h) equilíbrio de mercado - por fim, a AED pretende alcançar a justiça por meio da eliminação de desperdícios, ou seja, quanto mais eficientes são as escolhas dos agentes, melhor os recursos escassos são alocados e, portanto, mais justa é sua distribuição na sociedade.

Vale lembrar que essa AED é entendida como consequencialista e criticada pelo fato de não avaliar os valores levados em conta na alocação dos recursos, apenas a alocação em si, realizada da forma mais eficiente possível. Amartya Sen entende que "os direitos e liberdades 
devem ser temas centrais, não meros instrumentos de bem-estar”. Segundo ele, devem ser considerados os valores envolvidos nas escolhas, não podendo a eficiência sobrepor-se a valores como a vida e a liberdade.

O Primeiro Teorema do Bem-Estar Social diz respeito, justamente, à eficiência do mercado, que busca o equilíbrio competitivo por meio do cruzamento entre a curva da oferta e a curva demanda. No entanto, existem constantes desequilíbrios causados por falhas de mercado.

De acordo com Porto, essas falhas são situações externas ao próprio mercado, por isso são considerados externalidades os custos ou benefícios advindos de ações de agentes, que são impostos a terceiros ou mesmo ao agente causador. As externalidades serão internas quando quem deu causa aos custos/benefícios os suporta; e serão externalidades externas quando quem as suporta é um terceiro. Impondo custos, tratar-se-á de externalidades negativas; impondo benefícios, positivas ${ }^{8}$.

A fim de tornar as falhas de mercado mais claras, suponhamos a existência de um conjunto de imóveis localizado em uma rua sem saída. Caso a autoridade de tráfego realize a abertura da rua em prol de melhorias no trânsito, e caso tratem-se de imóveis residenciais que terão sua paz afetada, a hipótese dirá respeito a uma externalidade externa negativa (custo imposto pela autoridade a terceiros); mas caso tratem-se de imóveis comerciais que aumentarão seu número de clientes, a hipótese seria de externalidade externa positiva (benefício imposto pela autoridade a terceiros).

Entretanto, caso a abertura da rua sem saída ocorra devido a uma reivindicação de lojistas para seu benefício, sendo eles proprietários daqueles imóveis, a hipótese seria de externalidade interna positiva (benefício pela própria ação). As externalidades podem ser ilustradas em um sem número de hipóteses, mas estas parecem suficientes.

Ronald Coase considera as externalidades como custo social e a solução que apresenta para os desequilíbrios que causam foi exposta na obra 'O problema do custo social'. Para o autor, os custos de transação são a somatória dos custos privados de quem age e do impacto suportado por terceiros, isto porque, para ele, a externalidade deve ser suportada pela parte que a absorver com menor custo, tenha ou não lhe dado causa.

Custos de transação são os custos inerentes ao negócio, desde os custos de busca de parceiros para negócios, passando pelos custos da negociação em si - manter o estabelecimento comercial ou realizar reuniões, por exemplo - até os custos de execução do contrato firmado.

8 PORTO, Antônio José Maristrello. Análise Econômica do Direito (AED). Rio de Janeiro: Fundação Getúlio Vargas, 2013. p. 26-8. 
A ideia defendida por Coase é a de que a intervenção estatal prejudica o alcance da eficiência do mercado, uma vez que o equilíbrio pode ser alcançado quando existe uma definição clara do direito de propriedade e inexistem custos de transação entre os agentes, num contexto de mercado perfeito.

A intervenção permitida por Coase reserva-se aos casos em que os custos de transação são tão altos que a negociação se torna impossível, situação que dependerá do modo de atribuição dos direitos de propriedade. Sendo assim, quanto mais livre o mercado, maior sua eficiência e menores serão os custos sociais.

Esse é o fundamento do Teorema Normativo de Coase, donde se conclui que se deve estruturar o direito de modo a mover os impedimentos aos acordos privados ${ }^{9}$. Ou seja, segundo Maurício Vaz Lobo Bittencourt, “as regras jurídicas devem ser julgadas pela estrutura de incentivos que estabelecem e as consequências de como as pessoas alteram seu comportamento em resposta a esses incentivos" ${ }^{10}$.

Já na perspectiva de Guido Calabresi, que fazia oposição a Coase, as trocas são voluntárias e o mercado não precisa de intervenção quando os custos de transação são baixos, mas sim quando são altos, não bastando normas claras, pois o remédio jurídico que tem maior eficiência aos obstáculos à cooperação é a concessão de indenização pecuniária ${ }^{11}$, o que permitiria o reequilíbrio.

Douglass North também discordava de Coase ao afirmar que é necessária "a criação de instituições [políticas ou econômicas] que estruturem as regras e sua aplicação de modo a alterar as recompensas para induzir soluções cooperativas"12, isto porque, para ele, "a taxa de aprendizado determina a velocidade da mudança econômica, o tipo de aprendizado determina a

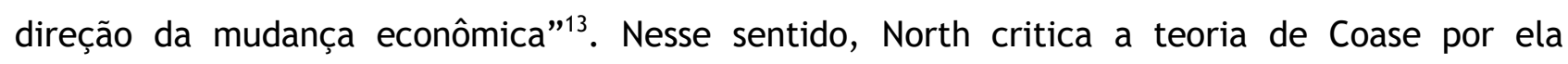
considerar a alocação de recursos de modo estático, a partir chamou de 'firma', ao passo que North percebe o mercado como dinâmico, em que as trocas servem como aprendizado, minimizando a racionalidade limitada de seus agentes.

\footnotetext{
9 PORTO, Antônio José Maristrello. Análise Econômica do Direito (AED). Rio de Janeiro: Fundação Getúlio Vargas, 2013. p. 44.

10 BITTENCOURT, Maurício Vaz Lobo. Princípio da Eficiência. In: RIBEIRO, Márcia Carla Pereira; KLEIN, Vinícius (Coord.) $O$ que é análise econômica do direito: uma introdução. Belo Horizonte: Fórum, 2011. p. 28.

11 PORTO, Antônio José Maristrello. Análise Econômica do Direito (AED). Rio de Janeiro: Fundação Getúlio Vargas, 2013. p. 46.

12 NORTH, Douglass C. The new institutional economics and third world development. In: The new institutional economics and third world development. Routledge, 2003. p. 35.

13 NORTH, Douglass C. The new institutional economics and third world development. In: The new institutional economics and third world development. Routledge, 2003. p. 36.
} 
Apesar disso, Coase e North fazem parte da corrente teórica denominada por Oliver Williamson como "Nova Economia Institucional" ${ }^{14}$ As ideias de North "convergem com trabalho clássico de Coase, em 1937, que explica a existência de empresas pelos custos na utilização do mercado e nas transações” ${ }^{15}$ Trata-se de uma das suas grandes contribuições, pois, ao enfocar a racionalidade limitada e o oportunismo, a complexidade, a incerteza e a especificidade dos ativos, mostra como se altera a organização das empresas.

Além deles, Williamson tem uma visão muito próxima da de Coase sobre a existência dos custos de transação, mas sua abordagem é mais profunda, incluindo os aspectos internos de organização da firma. Williamson afirma, em "Custos de transação econômicos: a governança dos Contratos Relacionais" que seu trabalho

Tenta corrigir essa deficiência e identifica a incerteza, frequência de troca e o grau em que os investimentos são específicos de transação como as principais dimensões para descrever as transações. A organização eficiente da atividade econômica implica combinar as estruturas de governança com esses atributos transacionais de maneira discriminatória ${ }^{16}$

Ou seja, partindo de Coase, seguido por North e Williamson, a Nova Economia Institucional analisa os custos de transação inicialmente pela 'firma' para avançar em suas relações internas e externas.

Em qualquer dos casos, a ética é consequencialista uma vez que, para a AED, as regras da sociedade devem levar em conta a estrutura de incentivos dos agentes afetados e a possibilidade de eles mudarem a conduta caso essas regras sejam alteradas. Assim, pode-se afirmar que "a AED é a aplicação de uma 'eficiência' às normas"17.

A eficiente circulação de riqueza é buscada pelo Equilíbrio de Mercado. Para Vilfredo Pareto, um mercado será equilibrado quando ocorra "o incremento da situação de qualquer indivíduo sem implicar prejuízos a terceiros”18 - esta situação representa a 'melhora de Pareto'.

${ }^{14}$ LOPES, Herton Castiglioni. Instituições e crescimento econômico: os modelos teóricos de Thorstein Veblen e Douglass North. Revista de Economia Política, v. 33, n. 4, 2013. p. 620.

15 LOPES, 2013. p. 623.

${ }^{16}$ WILLIAMSON, Oliver E. Custos de Transação Econômicos: a governança dos Contratos Relacionais. Jornal de Direito e Economia, v. 22, n. 2, p. 233-261, 1979. p. 261.

17 PORTO, Antônio José Maristrello. Análise Econômica do Direito (AED). Rio de Janeiro: Fundação Getúlio Vargas, 2013. p. 12.

${ }^{18}$ DOMINGUES, Vitor Hugo. Ótimo de Pareto. In: RIBEIRO, Márcia Carla Pereira; KLEIN, Vinícius (Coord.) 0 que é análise econômica do direito: uma introdução. Belo Horizonte: Fórum, 2011. p. 39. 
O critério proposto por Pareto é o usual, "segundo o qual os bens são transferidos de quem os valoriza menos a quem lhes dá mais valor"19.

De acordo com Bruno Salama,

O italiano Vilfredo Pareto concebera o conceito de "melhora" como uma forma de resolver o principal problema prático do utilitarismo - a impossibilidade de mensuração de felicidade. Geralmente, a única forma de se constatar a existência de uma "melhora" de Pareto é demonstrando que todos os envolvidos consentiram com a mudança ${ }^{20}$.

Ao chegar nesse patamar, Domingues explica que foi atingido o ponto 'Ótimo de Pareto', também chamado 'Pareto Eficiente', que “é o exato momento de equilíbrio em que todas as ações a serem tomadas não incrementam a condição dos agentes sem prejudicar outros"21.

No entanto, a situação de 'Ótimo de Pareto' pressupõe inalterabilidade, o que manteria desigualdades. Nesse sentido, Salama afirma que "o critério de Pareto, se utilizado como norte para a construção jurídica, faria então com que a lei perdesse toda a sua plasticidade, fatalmente condenando a sociedade à petrificação, ao imobilismo e à injustiça"22. Corrobora com tal entendimento Domingues, quando explica que "o critério de eficiência de Pareto não dá conta de comparar duas situações 'ótimas"”23.

Diante das críticas, “o critério de eficiência apresentado por Pareto sofisticou-se ao longo do tempo, e um dos precursores desta mudança foi Alfred Marshal, (...) que propôs um novo conceito de melhoria"24; em que seria possível a compensação entre ganhadores e

19 SZTAJN, Rachel. Law and Economics. In: ZYLBERSZTAJN, Decio; SZTAJN, Rachel (Org.). Direito \& Economia: Análise Econômica do Direito e das Organizações. São Paulo: Elsevier Editora Ltda., 2005. p. 103.

20 SALAMA, Bruno Meyerhof. A História do Declínio e Queda do Eficientismo na Obra de Richard Posner. In: LIMA, Maria Lúcia L. M. Pádua (org.). Trinta Anos de Brasil: Diálogos entre Direito e Economia. São Paulo: Saraiva, 2012. Republicado: Revista do Instituto do Direito Brasileiro da Faculdade de Direito da Universidade de Lisboa (RIDB), n. 1, 2012. Disponível em: https://works.bepress.com/bruno_meyerhof_salama/35. Acesso em 01 nov. 2019. p. 20.

${ }^{21}$ DOMINGUES, Vitor Hugo. Ótimo de Pareto. In: RIBEIRO, Márcia Carla Pereira; KLEIN, Vinícius (Coord.) 0 que é análise econômica do direito: uma introdução. Belo Horizonte: Fórum, 2011. p. 40-1.

22 SALAMA, Bruno Meyerhof. A História do Declínio e Queda do Eficientismo na Obra de Richard Posner. In: LIMA, Maria Lúcia L. M. Pádua (org.). Trinta Anos de Brasil: Diálogos entre Direito e Economia. São Paulo: Saraiva, 2012. Republicado: Revista do Instituto do Direito Brasileiro da Faculdade de Direito da Universidade de Lisboa (RIDB), n. 1, 2012. Disponível em: https://works.bepress.com/bruno_meyerhof_salama/35. Acesso em 01 nov. 2019. p. 20.

${ }^{23}$ DOMINGUES, Vitor Hugo. Ótimo de Pareto. In: RIBEIRO, Márcia Carla Pereira; KLEIN, Vinícius (Coord.) 0 que é análise econômica do direito: uma introdução. Belo Horizonte: Fórum, 2011. p. 42.

24 DOMINGUES, Vitor Hugo. Ótimo de Pareto. In: RIBEIRO, Márcia Carla Pereira; KLEIN, Vinícius (Coord.) 0 que é análise econômica do direito: uma introdução. Belo Horizonte: Fórum, 2011. p. 42. 
perdedores para que fossem realizadas mudanças. "Tal critério corresponde também ao que em análise econômica antecedeu os estudos de Nicholas Kaldor e Jhon Hicks, mais conhecido como 'Teorema de Kaldor-Hicks'25”.

Pelo critério de Kaldor-Hicks, o importante é que os ganhadores possam potencialmente compensar os perdedores, mesmo que efetivamente não o façam. Desse modo, o critério de Kaldor-Hicks permite que mudanças sejam feitas ainda que haja "perdedores"26.

Richard Posner associou a eficiência de Pareto com a de Kaldor-Hicks e passou a aplicálas em suas decisões, o que influenciou a ampliação da aplicação da AED nas decisões judiciais, uma vez que, economista, atuava como juiz do Sétimo Circuito da Corte de Apelações dos Estados Unidos ${ }^{27}$.

Segundo Salama,

0 argumento central da teoria formulada por Posner é simples: o direito norteamericano não apenas tem evoluído historicamente no sentido da eficiência; o direito norte-americano deve evoluir (ou talvez, deve continuar evoluindo) no sentido da eficiência. A este argumento Posner deu o nome de teoria da "maximização da riqueza"28.

A esse respeito Salama afirma que Posner utiliza a racionalidade como uma "premissa instrumental para formulação de hipóteses(...)", entendendo que "a premissa metodológica de maximização racional pode ser útil porque o comportamento racional é geralmente previsível, enquanto que o comportamento irracional é geralmente aleatório"29.

${ }^{25}$ DOMINGUES, Vitor Hugo. Ótimo de Pareto. In: RIBEIRO, Márcia Carla Pereira; KLEIN, Vinícius (Coord.) 0 que é análise econômica do direito: uma introdução. Belo Horizonte: Fórum, 2011. p. 44.

${ }^{26}$ SALAMA, Bruno Meyerhof. A História do Declínio e Queda do Eficientismo na Obra de Richard Posner. In: LIMA, Maria Lúcia L. M. Pádua (org.). Trinta Anos de Brasil: Diálogos entre Direito e Economia. São Paulo: Saraiva, 2012. Republicado: Revista do Instituto do Direito Brasileiro da Faculdade de Direito da Universidade de Lisboa (RIDB), n. 1, 2012. Disponível em: https://works.bepress.com/bruno_meyerhof_salama/35. Acesso em 01 nov. 2019. p. 21.

27 PORTO, Antônio José Maristrello. Análise Econômica do Direito (AED). Rio de Janeiro: Fundação Getúlio Vargas, 2013. p. 12.

${ }^{28}$ SALAMA, Bruno Meyerhof. A História do Declínio e Queda do Eficientismo na Obra de Richard Posner. In: LIMA, Maria Lúcia L. M. Pádua (org.). Trinta Anos de Brasil: Diálogos entre Direito e Economia. São Paulo: Saraiva, 2012. Republicado: Revista do Instituto do Direito Brasileiro da Faculdade de Direito da Universidade de Lisboa (RIDB), n. 1, 2012. Disponível em: https://works.bepress.com/bruno_meyerhof_salama/35. Acesso em 01 nov. 2019. p. 5.

${ }^{29}$ SALAMA, Bruno Meyerhof. A História do Declínio e Queda do Eficientismo na Obra de Richard Posner. In: LIMA, Maria Lúcia L. M. Pádua (org.). Trinta Anos de Brasil: Diálogos entre Direito e Economia. São Paulo: Saraiva, 2012. Republicado: Revista do Instituto do Direito Brasileiro da Faculdade de Direito da 
A racionalidade limitada citada por Posner diz respeito à Conduta Racional Maximizadora, pressuposto teórico do Mercado Perfeito, base da Análise Econômica do Direito. Essa racionalidade, posto que teórica, que pode ser rompida por diversos fatores.

Segundo Márcia Carla Pereira Ribeiro, “prazer, ideias, objetivos indiretos podem influenciar o poder de escolha do contratante. Nessa circunstância, apontam as falhas de racionalidade que podem comprometer a eficiência que o modelo clássico associa às escolhas das partes no negócio"30.

Em resumo, a Análise Econômica do Direito busca a eficiência do mercado por meio de normas que maximizem a eficiência das escolhas dos sujeitos. Tais normas procuram alcançar pontos máximos de eficiência, como o de Pareto ou de Kaldor-Hicks. No entanto, as falhas de mercado como externalidades e racionalidade limitada impedem a perfeição do modelo proposto. Os desafios da AED encontram-se, justamente, no fato de que o mercado é imperfeito.

Passar-se-á, por hora, à análise da Desconsideração da Personalidade Jurídica justamente porque esta teoria pressupõe imperfeição na utilização da Personalidade Jurídica.

\section{DESCONSIDERAÇÃO DA PERSONALIDADE JURÍDICA}

Para desconsiderar a personalidade jurídica é necessário, antes, tratar da própria personalidade jurídica. Isto porque é necessário entender sua existência para, então, pensar em desconsiderá-la.

Sobre esse assunto entende Bastos que "as pessoas jurídicas são sujeitos de direitos e obrigações criadas com o objetivo de atingir a uma determinada finalidade, contando para isso com uma autonomia própria e independente de seus sócios" 31 . Corrobora com esse entendimento o conceito de Marlon Tomazette de que "não é a simples condição de sujeito de direitos que caracteriza a personalidade, mas a aptidão genérica para tanto, uma vez que os entes despersonificados também podem praticar atos jurídicos (...)"32. "Trata-se de um instrumento

Universidade de Lisboa (RIDB), n. $1, \quad 2012$. Disponível em:
https://works.bepress.com/bruno_meyerhof_salama/35. Acesso em 01 nov. 2019. p. 7.

${ }_{30}$ RIBEIRO, Márcia Carla Pereira. Racionalidade Limitada. In: RIBEIRO, Márcia Carla Pereira; KLEIN, Vinícius (Coord.) O que é análise econômica do direito: uma introdução. Belo Horizonte: Fórum, 2011. p. 66.

31 BASTOS, Luciana de Castro. A Desconsideração da Personalidade Jurídica e a Empresa Familiar. Porto Alegre, RS: Editora Fi, 2019. p. 44.

32 TOMAZETTE, Marlon. Curso de Direito Empresarial: Teoria Geral e Direito Societário. 8. ed., São Paulo: Atlas, 2017, 1. v. p. 294. 
criado pelo direito para viabilizar, incentivar, facilitar o desenvolvimento de atividades e a produção de resultados desejados pelo ordenamento jurídico"33.

Ou seja, a personalidade jurídica é uma ficção capaz de adquirir direitos e contrair obrigações. Nesse sentido, Fábio Ulhoa Coelho esclarece que a principal consequência da personificação das pessoas jurídicas

É a autonomia patrimonial. A separação entre os patrimônios da pessoa jurídica e os das pessoas que a compõem gera importantes consequências no tocante à responsabilidade patrimonial, posto que pelas obrigações dos membros da pessoa jurídica não responde o patrimônio da pessoa jurídica, nem pelas obrigações desta será possível alcançar o patrimônio individual de um seu membro, senão em hipóteses excepcionais e raras, e, mesmo assim, de forma subsidiária ${ }^{34}$.

Apesar da construção histórica da pessoa jurídica em prol das pessoas físicas, essas mesmas passaram a utilizar a ficção criada de forma abusiva. Os inúmeros casos levados às cortes do mundo todo fizeram com que o cenário da personalidade jurídica adquirisse novos contornos.

Segundo Koury, a primeira manifestação sobre a Desconsideração da Personalidade Jurídica foi da jurisprudência norte-americana em 1809, "no caso Bank of United v. Deveaux, [quando] o Juiz Marshall, com a intenção de preservar a jurisdição das cortes federais sobre as corporations (...) conheceu da causa, por considerar as características pessoais dos sócios”35.

A doutrina norte americana, entretanto, não recebeu tanto destaque, ainda que desconsiderasse as Pessoas Jurídicas entendendo que elas mesmas não eram respeitadas por seus sócios $^{36}$. Essa decisão foi cronologicamente anterior, mas não foi norte-americana a decisãoparadigma da teoria da Desconsideração da Personalidade Jurídica.

Esclarece Souza que “a doutrina em questão teria nascido na Inglaterra, em 1897, quando o Poder Judiciário desse país julgou o caso Salomon v. Salomon \& Co."37. O caso tratava da utilização da Pessoa Jurídica para prejudicar credores, o que viria se se tornar a essência da teoria da Desconsideração da Personalidade Jurídica.

33 TALAMINI, Eduardo. Incidente de desconsideração da personalidade jurídica. Migalhas. 02 de março de 2016. Disponível em: https://www.migalhas.com.br/dePeso/16,Ml234997,11049Incidente+de+desconsideracao+de+personalidade+juridica. Acesso em: 01 nov. 2019.

${ }^{34}$ COELHO, Fábio Ulhoa. Desconsideração da Personalidade Jurídica. São Paulo: Editora Revista dos Tribunais, 1989. p. 13.

${ }^{35}$ KOURY, Suzy Elizabeth Cavalcante. A desconsideração da personalidade jurídica (disregard doctrine) e os grupos de empresas. 4. ed. São Paulo: LTr, 2018. p. 65.

36 OLIVEIRA, José Lamartine Correia de. A dupla crise da pessoa jurídica. São Paulo: Saraiva, 1979. p. 262-3.

37 SOUZA, André Pagani de. Desconsideração da personalidade jurídica: aspectos processuais. 2. ed., São Paulo: Saraiva, 2011, E-book. p. 106. 
Mas foi a doutrina alemã a que mais se preocupou com o tema. Expoente dessa doutrina foi Rolf Serick, que estabeleceu hipóteses para aplicação da Desconsideração da Personalidade Jurídica.

$\mathrm{Na}$ lição de Coelho, "o primeiro caso de aplicação da teoria do disregard seria a hipótese de fraude à lei"38, nas situações em que "se a pessoa jurídica for utilizada para fins diversos [ilícitos] dos que justificam a sua criação pelo ordenamento jurídico, esta separação poderá inocorrer"39.

O segundo caso, “de fraude a obrigações contratuais" 40 , de acordo com Coelho, é o que considera que "o princípio da autonomia da pessoa jurídica é válido e apenas se condena o mal uso [ilicitude] que se the possa imprimir"41.

O terceiro caso, "de fraude contra credores"42, estabelece que "somente quando se verifica que há incompatibilidade entre os objetivos da norma jurídica relativa ao ser humano e a função da pessoa jurídica, é que não será admissível sua aplicação [casos de confusão patrimonial]"43.

Por fim, a quarta hipótese, “de vinculação entre duas sociedades" ${ }^{44}$, aponta a existência de ligação entre duas sociedades, situação em que uma sociedade realiza negócio com outra que é sua integrante ${ }^{45}$.

Outro importante nome dos estudos iniciais da DPJ é Pierro Verrucoli, italiano, para o qual a personalização da pessoa jurídica é "um privilégio para os seus integrantes, no sentido de poderem existir e agir unitariamente, como um grupo. E enquanto um privilégio outorgado pelo

38 OLIVEIRA, José Lamartine Correia de. A dupla crise da pessoa jurídica. São Paulo: Saraiva, 1979. p. 273.

39 COELHO, Fábio Ulhoa. Desconsideração da Personalidade Jurídica. São Paulo: Editora Revista dos Tribunais, 1989. p. 18.

40 OLIVEIRA, José Lamartine Correia de. A dupla crise da pessoa jurídica. São Paulo: Saraiva, 1979. p. 274.

41 COELHO, Fábio Ulhoa. Desconsideração da Personalidade Jurídica. São Paulo: Editora Revista dos Tribunais, 1989. p. 19.

42 OLIVEIRA, José Lamartine Correia de. A dupla crise da pessoa jurídica. São Paulo: Saraiva, 1979. p. 274.

43 COELHO, Fábio Ulhoa. Desconsideração da Personalidade Jurídica. São Paulo: Editora Revista dos Tribunais, 1989. p. 22.

${ }^{44}$ OLIVEIRA, José Lamartine Correia de. A dupla crise da pessoa jurídica. São Paulo: Saraiva, 1979. p. 275.

45 COELHO, Fábio Ulhoa. Desconsideração da Personalidade Jurídica. São Paulo: Editora Revista dos Tribunais, 1989. p.22. 
Estado aos sócios, a personalização jurídica da sociedade não poderá servir à criação de situações injustas"46.

Sobre ser um privilégio, segundo $\mathrm{Koury}^{47}$, o Verrucoli "quer afirmar que o reconhecimento da personalidade jurídica é sempre uma criação do direito na medida em que é consentida, reconhecida e tutelada esta liberdade de formação e expressão coletiva”.

De acordo com Coelho,

Para Verrucoli, a Common Law e a Civil Law diferem-se pelos 'escrúpulos' teóricos que o sistema possui para possibilitar o afastamento da personalização das pessoas jurídicas. Enquanto a Common Law, um sistema mais aberto, não se preocupa muito com a precisa definição de uma teoria sistematizadora, a partir da qual fosse autorizada a desconsideração da autonomia patrimonial das pessoas jurídicas, a Civil Law tem esta preocupação bem acentuada ${ }^{48}$.

$\mathrm{Na}$ doutrina nacional destacam-se, por seu trabalho, Rubens Requião que, em Conferência realizada na Faculdade de Direito da Universidade Federal do Paraná, em comemoração ao aniversário de 100 anos de seu primeiro catedrático de Direito Comercial, o Desembargador Vieira Cavalcanti Filho, no ano de 1969, deu início às discussões acerca do tema da Desconsideração da Personalidade Jurídica. Inclusive, pode ser ele apontado como o responsável por cunhar tal expressão, posto tê-la utilizado na explanação que deu sobre o assunto naquela ocasião.

Segundo o autor, a personalidade jurídica é criação legal do Estado, que pode verificar sua adequada utilização, por isso, “a personalidade jurídica passa a ser considerada doutrinariamente um direito relativo, permitindo ao juiz penetrar o véu da personalidade para coibir os abusos ou condenar a fraude, através de seu uso" ${ }^{\text {49. }}$

Ainda, entende Requião que o indivíduo, “[n]o exercício de seus direitos, embora privados, deve atender a uma finalidade social" ${ }^{50}$. Nesse sentido, para o autor, a DPJ, mesmo quando não prevista em lei, é necessária para reprimir atitudes contrárias à citada finalidade social do direito.

${ }^{46}$ COELHO, Fábio Ulhoa. Desconsideração da Personalidade Jurídica. São Paulo: Editora Revista dos Tribunais, 1989. p.25.

47 KOURY, Suzy Elizabeth Cavalcante. A desconsideração da personalidade jurídica (disregard doctrine) e os grupos de empresas. 4. ed. São Paulo: LTr, 2018. p. 23.

${ }^{48}$ COELHO, Fábio Ulhoa. Desconsideração da Personalidade Jurídica. São Paulo: Editora Revista dos Tribunais, 1989. p. 32.

49 REQUIÃO, Rubens. Abuso de Direito e fraude através da personalidade jurídica. Revista dos Tribunais. São Paulo, volume 410, ano 58, p. 12-24, dezembro, 1969. p. 15.

${ }^{50}$ REQUIÃO, Rubens. Abuso de Direito e fraude através da personalidade jurídica. Revista dos Tribunais. São Paulo, volume 410, ano 58, p. 12-24, dezembro, 1969. p. 16. 
O entendimento de Fábio Konder Comparato segue rumo semelhante ao estabelecer que nos casos em que a personalidade jurídica não atender a sua finalidade, ela deve ser desconsiderada. No entanto, o autor estabelece pressupostos a serem observados para que a desconsideração ocorra. Nas palavras de Comparato, a separação patrimonial, que é o principal efeito jurídico da personalização jurídica,

Deve ser normalmente afastado quando falte um dos pressupostos formais, estabelecidos em lei; e, também, quando desapareça a especificidade [pressupostos substanciais] do objeto social de exploração de uma empresa determinada ou do objeto social de produção e distribuição de lucro - ou, ainda, quando ambos se confundirem com a atividade ou o interesse individuais de determinado sócio ${ }^{51}$.

Para ele, a sanção jurídica, em tais casos, "não deve ser, indistintamente, a nulidade (absoluta ou relativa) do ato, negócio, ou da relação, mas a ineficácia. Não deve ser a destruição da "entidade” pessoa jurídica, mas a suspensão dos efeitos da separação patrimonial in casu"52.

Em resumo, Comparato estabelece que inobservados os pressupostos formais (previsão legal) ou os substanciais (objeto e objetivos da pessoa jurídica), a personalidade jurídica deve ser desconsiderada.

Ao tratar de pressupostos, Comparato inaugura a teoria objetiva da DPJ, em contraposição à teoria subjetiva de Rolf Serick, isso porque, para este, a 'intenção' do sócio deveria ser levada em consideração.

Coelho, no entanto, discorda da concepção objetiva de Comparato e afirma que ela "não logrou alcançar uma formulação satisfatória" 53 por dois aspectos. Primeiro porque "antes de gerar a desconsideração da personalização de uma sociedade, a ausência de pressuposto formal gera a sua inexistência ou irregularidade" 54 . Segundo, porque ao tratar dos pressupostos substanciais, Comparato refere-se à fraude e ao abuso do direito e Coelho entende que a escolha dessas condutas “como principais hipóteses de aplicação da teoria implica na impossibilidade de

51 COMPARATO, Fábio Konder. 0 poder de controle na sociedade anônima. São Paulo: Revista dos Tribunais, 1977. p. 270.

52 COMPARATO, Fábio Konder. 0 poder de controle na sociedade anônima. São Paulo: Revista dos Tribunais, 1977. p. 271-2.

53 COELHO, Fábio Ulhoa. Desconsideração da Personalidade Jurídica. São Paulo: Editora Revista dos Tribunais, 1989. p. 42.

54 COELHO, Fábio Ulhoa. Desconsideração da Personalidade Jurídica. São Paulo: Editora Revista dos Tribunais, 1989. P. 42. 
se desconsiderar em favor de membros da pessoa jurídica ou da própria [sociedade]"55, considerando, assim, tais hipóteses insuficientes.

Para Coelho, Comparato tem razão ao criticar o entendimento subjetivista de Serick, mas erra ao descartá-lo; segundo o autor, "a formulação subjetiva deverá ser despida da ênfase que Rolf Serick confere ao elemento intencional, de molde a se chegar a um resultado, por assim dizer, intermediário" ${ }^{56}$. Ou seja, a teoria defendida por Coelho estabelece-se próxima da subjetiva, mas sem o elemento anímico, podendo ser considerada um tipo de teoria subjetiva mitigada.

O conceito de Desconsideração da Personalidade Jurídica apresentado por Coelho é o de que “o juiz pode decretar a suspensão episódica da eficácia do ato constitutivo da pessoa jurídica, se verificar que ela foi usada como instrumento para a realização de fraude ou abuso de direito" 57 .

Oliveira entende que a DPJ é "uma espécie de suspensão de vigência - para o caso concreto em julgamento - do princípio da separação entre pessoa jurídica e pessoa-membro" 58 .

Flávio Tartuce conceitua o instituto considerando que ele

Permite ao juiz não mais considerar os efeitos da personificação da sociedade para atingir e vincular responsabilidades dos sócios e administradores, com intuito de impedir a consumação de fraudes e abusos por eles cometidos, desde que causem prejuízos e danos a terceiros, principalmente a credores da empresa ${ }^{59}$.

Observa-se deste último conceito, a necessidade de o abuso ou fraude terem causado prejuízos ou danos a terceiros. Ainda assim essa construção pode ser considerada como adepta da Teoria Maior da Desconsideração da Personalidade Jurídica; na contramão do que determina a Teoria Menor.

55 COELHO, Fábio Ulhoa. Desconsideração da Personalidade Jurídica. São Paulo: Editora Revista dos Tribunais, 1989. p. 43.

56 COELHO, Fábio Ulhoa. Desconsideração da Personalidade Jurídica. São Paulo: Editora Revista dos Tribunais, 1989. p. 45.

57 COELHO, Fábio Ulhoa. Desconsideração da Personalidade Jurídica. São Paulo: Editora Revista dos Tribunais, 1989. p. 54.

${ }^{58}$ OLIVEIRA, José Lamartine Correia de. A dupla crise da pessoa jurídica. São Paulo: Saraiva, 1979. p. 262.

59 TARTUCE, Flávio. A Desconsideração da Personalidade Jurídica e suas aplicações ao Direito de Família e das Sucessões. Migalhas, 25 de outubro de 2017. Disponível em: https: / / www.migalhas.com.br/FamiliaeSucessoes/104,MI267804,51045-

A+desconsideracao+da+personalidade+juridica+e+suas+aplicacoes+ao. Acesso em: 01 nov. 2019. 
Depreende-se do que se apresentou até o momento que a Desconsideração da Personalidade Jurídica surgiu “como reação contra aqueles que se valessem a posteriori da personificação societária para a obtenção de resultado reprovável"60.

Acerca das teorias da DPJ, tem-se que a aplicação da Teoria Maior ocorre quando, para a desconsideração, é observado o critério do comprovado abuso de personalidade jurídica, descrito no art. 50 do Código Civil Brasileiro como desvio de finalidade da sociedade ou confusão patrimonial.

Em 2019 este artigo sofreu alterações pela Lei da Liberdade Econômica (Lei 13.874/2019), pelo acréscimo, ao final da redação do caput, de que o patrimônio a ser atingido será dos "beneficiados direta ou indiretamente pelo abuso", o que pode ser considerado mais um pressuposto a ser observado na aplicação do instituto da desconsideração, pois ficam excluídos aqueles que não se beneficiaram do abuso cometido por meio da pessoa jurídica. Além disso, a recente lei ainda acrescentou parágrafos ao art. 50 CC de modo a garantir que os pressupostos sejam observados e que apenas aqueles que abusaram do direito da pessoa jurídica respondam por seus atos.

Já a Teoria Menor não observa critérios, apenas determina a desconsideração quando a pessoa jurídica for, de alguma forma, obstáculo ao ressarcimento de prejuízos causados pela sociedade, nos termos do art. $28, \$ 5^{\circ}$ do Código de Defesa do Consumidor, que representa a primeira positivação da Desconsideração da Personalidade Jurídica.

O impacto dessa previsão foi tamanho que, segundo Rodrigo Xavier Leonardo,

Desse dispositivo do Código de Defesa do Consumidor sobreveio regra no direito ambiental, o artigo $4^{\circ}$ da Lei 9.605/98; regra para atividade de distribuição de combustível da Lei 9.847/99; para exploração de hidrocarbonetos; no direito da concorrência; no direito civil; fora regras do direito do trabalho e do direito tributário que, ainda que não tratem de Desconsideração da Pessoa Jurídica, são aplicadas como se fossem regras de Desconsideração da Pessoa Jurídica por centenas e centenas de acórdãos ${ }^{61}$.

Corrobora com esse entendimento a pesquisa realizada por Tomazette que registrou que “a orientação majoritária na jurisprudência trabalhista é a de aplicação da desconsideração,

${ }^{60}$ KOURY, Suzy Elizabeth Cavalcante. A desconsideração da personalidade jurídica (disregard doctrine) e os grupos de empresas. 4. ed. São Paulo: LTr, 2018. p. 70.

${ }^{61}$ LEONARDO, Rodrigo Xavier. Palestra: Desconsideração da Personalidade Jurídica. In: Congresso da Liberdade Econômica da OAB/PR, 1., Curitiba, 17 out. 2019. 
independentemente de qualquer prova de abuso da personalidade jurídica"62, ou seja, pela Teoria Menor.

No mesmo sentido alerta Schreiber que o STJ decidiu que a Teoria Menor da desconsideração que foi "acolhida em nosso ordenamento jurídico excepcionalmente no Direito do Consumidor e no Direito Ambiental, incide com a mera prova de insolvência da pessoa jurídica para o pagamento de suas obrigações, independentemente da existência de desvio de finalidade ou de confusão patrimonial"63.

Depreende-se do analisado que, em regra, a Teoria Menor é aplicada em diferentes ramos sem observação de critérios, bastando que a pessoa jurídica não seja capaz de saldar sua dívida - momento em que os sócios passam a pagá-las com patrimônio pessoal.

Sobre as teorias da desconsideração, Farias e Rosenvald explicam que

[...] para a teoria maior, a desconsideração depende de requisito específico, razão pela qual nem todo caso de responsabilização pessoal do sócio configura hipótese de incidência do disregard doctrine, enquanto a teoria menor considera que toda e qualquer hipótese de responsabilização do sócio por dívida da empresa é um caso de desconsideração. De qualquer sorte, a teoria maior exigirá, sempre, o atendimento de requisitos legais específicos para efetivar a desconsideração.

De outra banda, a teoria menor ${ }^{64}$ [...] fundamenta o seu cerne no simples prejuízo do credor para afastar a autonomia patrimonial da pessoa jurídica ${ }^{65}$.

A escolha por uma ou outra teoria pode influenciar na forma como o pedido de desconsideração será processado. Isto pela nova previsão legal dos procedimentos a serem utilizados para desconsiderar-se a personalidade jurídica, a partir do Código de Processo Civil de 2015 (CPC/15). Esclarece-se.

Até o advento do $\mathrm{CPC} / 15$, não existia no ordenamento jurídico brasileiro previsão de procedimento para ocorrência deste instituto. Em tais casos, era o juiz quem decidia a maneira como a desconsideração iria acontecer. Isto gerava um problema aos sócios, que se viam parte nos processos de execução sem a possibilidade de discutir, adequadamente, a culpa, nos atos da sociedade, que ensejaria a desconsideração desta.

62 TOMAZETTE, Marlon. Curso de direito empresarial: Teoria geral e direito societário, 8. ed. rev. e atual., São Paulo: Atlas, 2017, 1. v. p. 333.

63 SCHREIBER, Anderson; et al. Código Civil comentado - doutrina e jurisprudência. Rio de Janeiro: Forense, 2019, E-book. p. 103.

64 COELHO, Fábio Ulhoa. Desconsideração da Personalidade Jurídica. São Paulo: Editora Revista dos Tribunais, 1989. p. 54-63.

65 FARIAS, Cristiano Chaves de; ROSENVALD, Nelson. Curso de Direito Civil: Parte Geral e LINDB. São Paulo: Editora Atlas S.A., 2015. p. 393. 
A defesa dos sócios, portanto, em regra, era a oposição de embargos de terceiro, uma vez que não tinham participado das discussões acerca, especificamente, da desconsideração, mas precisaram tentar, de alguma forma, defender seu patrimônio pessoal.

Com o Novo Código Civil inaugurou-se a previsão processual do instituto, garantindo-se aos sócios ampla discussão sobre a desconsideração da personalidade da qual façam parte. Sendo feito o pedido de desconsideração já na petição inicial, a discussão a respeito da DPJ abrange todo o processo e propicia ampla defesa e contraditório durante o processo.

Mas sendo o pedido realizado posteriormente, o juiz deve iniciar um incidente processual, em que o processo inicial dá lugar, até que o incidente seja resolvido, à discussão acerca da utilização da pessoa jurídica pelos sócios, da participação de cada sócio nas atitudes que possam causar uma desconsideração e da determinação ou não da DPJ pelo juiz, com base, agora, numa instrução específica para o assunto, garantindo-se ampla defesa e contraditório aos sócios.

A Desconsideração da Personalidade Jurídica foi prevista, justamente, com o fim de garantir-se o princípio constitucional do contraditório aos sócios, como é possível conferir na exposição de motivos do CPC/15:

O Novo CPC prevê expressamente que, antecedida de contraditório e produção de provas, haja decisão sobre a desconsideração da pessoa jurídica, com o redirecionamento da ação, na dimensão de sua patrimonialidade, e também sobre a consideração dita inversa, nos casos em que se abusa da sociedade, para usá-la indevidamente com o fito de camuflar o patrimônio pessoal do sócio ${ }^{66}$.

A partir do exposto pode-se afirmar que a base material para a previsão processual da desconsideração é a Teoria Maior, posto que se considera o abuso do sócio como premissa para se atingir os sócios, corroborando com a intenção original desenvolvida pelos tribunais angloamericanos.

Dito isto, a utilização da Teoria Menor, ao não observar a conduta dos sócios para atingi-los, mas apenas a impossibilidade da pessoa jurídica em saldar suas dívidas com os credores. Inobserva, também, o próprio contraditório que o instituto pretende proteger, uma vez que não se discutem dados objetivos de saldo da empresa, prejudicando a proposta de defesa dos sócios.

${ }^{66}$ BRASIL, Lei 1.305 de 16 de março de 2015. Código de Processo Civil: anteprojeto / comissão de Juristas Responsável pela elaboração de Anteprojeto de Código Civil. Brasília: Senado Federal, Presidência, 2010. p. 15. 
Este prejuízo decorre do fato de que, diante da Teoria Menor, a causa da ausência de crédito da pessoa jurídica não é levada em consideração, o que pode levar a decisão da DPJ a atingir sócios que empregaram todos os esforços cabíveis na boa condução da empresa e, mesmo assim, terão seu patrimônio pessoal atingido.

As consequências disso podem ser estudadas a partir de diferentes perspectivas. Nesta pesquisa optou-se pela da Análise Econômica do Direito, em foco no item seguinte.

\section{A DESCONSIDERAÇÃO DA PERSONALIDADE JURÍDICA SOB A ÓTICA DA ANÁLISE ECONÔMICA DO DIREITO}

Inicialmente, é importante considerar que a Desconsideração da Personalidade Jurídica implica regras pré-estabelecidas, no sentido de que ao cometer abusos por meio da Pessoa Jurídica os sócios devem conhecer os riscos a que estão se submetendo.

A Análise Econômica do Direito, por sua vez, avalia o contexto inicial da situação e procura meios que o tornem mais eficiente e ampliem o bem-estar geral da comunidade em questão. O que vai de encontro à ideia de que a AED faz uma investigação utilitarista, sem importar-se com as consequências sociais de seus métodos. Ademais, justamente por ser um método as ações apenas tomam como base seus estudos, não se podendo afirmar que são por eles determinadas.

A confusão ocorre, segundo Rachel Sztajn, pela alteração histórica nos objetivos das normas de direito, pois "o direito romano privilegiava a eficiência das normas, notadamente no que diz respeito à integração dos povos por grandes codificações europeias no século XIX"; ao passo que "a fixação pelas fontes (...) deixa em segundo plano as transformações sociais ocorridas ao longo dos dois últimos séculos”67.

É possível afirmar, assim, que para a AED “a racionalidade dos agentes (...) e a eficiência alocativa (...) vão ao encontro da ideia de solidariedade e geração de bem-estar coletivo"68.

\footnotetext{
67 SZTAJN, Rachel. Law and Economics. In: ZYLBERSZTAJN, Decio; SZTAJN, Rachel (Org.). Direito \& Economia: Análise Econômica do Direito e das Organizações. São Paulo: Elsevier Editora Ltda., 2005. p. 106.

68 SZTAJN, Rachel. Law and Economics. In: ZYLBERSZTAJN, Decio; SZTAJN, Rachel (Org.). Direito \& Economia: Análise Econômica do Direito e das Organizações. São Paulo: Elsevier Editora Ltda., 2005. p. 104.
} 
Para Alvarez, o direito influi nos comportamentos de duas maneiras, "fixando preços para determinadas condutas" e sancionando "determinadas estruturas de direito, o que tem influência na eficiente alocação de recursos na sociedade". De acordo com o autor, "neste sentido, a análise econômica do direito é uma tentativa de dotar o pensamento jurídico de uma teoria que explique o comportamento dos indivíduos perante as regras e os efeitos destas na consecução de resultados eficientes" ${ }^{69}$.

Considerando, portanto, que a Análise Econômica do Direito está voltada às normas e à forma como elas impactam no bem-estar social, então a Desconsideração da Personalidade Jurídica quando aplicada mediante regras estabelecidas pode ser objeto de seus estudos.

Estabelecido o objeto de análise, pode-se verificar, então, se os impactos das normas vigentes destinadas à DPJ são positivos ou negativos segundo esse método.

Para tanto, vale ressaltar que a Desconsideração da Personalidade Jurídica tem duas teorias, já citadas: Teoria Maior e Teoria Menor de aplicação do instituto. Na primeira são observados requisitos para que a Pessoa Jurídica seja desconsiderada. Na segunda isso nem sempre acontece, visto que a falta de recursos para saldar dívidas da sociedade pode levar à desconsideração direta da PJ.

Segundo Mackaay e Rousseau, toda AED “está fundada na premissa de que as normas jurídicas devem ser julgadas à luz das estruturas de estímulos que estabelecem e das consequentes mudanças comportamentais adotadas pelos interessados em resposta aos estímulos"70. Assim, sob a perspectiva do método apontado pelos autores na obra "Análise Econômica de Direito', traduzida por Rachel Sztajn em 2015, inicialmente esta pesquisa tratará da Teoria Maior da DPJ.

De acordo com esses autores existem três níveis de análise em que se podem aplicar as etapas da AED. No primeiro nível, denominado 'análise dos efeitos das normas', “a análise econômica auxilia o jurista a determinar os principais efeitos da mudança da regra e, por ricochete, os efeitos da regra que não foi modificada"71. O segundo nível, 'o fundamento da norma', “visa a esclarecer um fundamento das regras que são observadas nos sistemas

\footnotetext{
${ }^{69}$ ALVAREZ, Alejandro Bugallo. Análise Econômica do Direito: Contribuições e desmistificações. Direito, Estado e Sociedade, Rio de Janeiro-RJ, v.9, n. 29, jul. /dez. 2006. p. 56.

70 MACKAAY, Ejan; ROUSSEAU, Stéphane. Análise Econômica do Direito. trad. Rachel Sztajn. 2.ed. São Paulo: Atlas, 2015. p. 666.

71 MACKAAY, Ejan; ROUSSEAU, Stéphane. Análise Econômica do Direito. trad. Rachel Sztajn. 2.ed. São Paulo: Atlas, 2015. p. 667.
} 
existentes"72. O terceiro nível, 'a regra desejável', “consiste em estabelecer os efeitos da norma e a julgá-la. Mais pontualmente, trata-se de determinar qual seria a norma eficiente e comparála à regra existente ou à considerada"73.

As etapas de que tratam os autores são quatro. Na primeira, denominada 'estrutura de incentivos', "pretende-se atualizar a estrutura de incentivos da norma"74. Isto porque, segundo Mackaay e Rousseau, o direito impõe ônus que a escolha racional dos indivíduos pretende diminuir. Para eles, "esta etapa é essencial no primeiro nível da análise econômica do direito (cálculo dos efeitos) e constitui primeiro passo nos dois outros níveis de análise (fundamento da regra; regra desejável)"75.

A segunda etapa, 'objetivos subjacentes', permite avaliar qual [das diferentes regras observadas na primeira etapa] atinge, no total, os custos mais baixos. Chega-se, dessa forma, ao nível 2 ou 3 da análise econômica do direito"76.

$\mathrm{Na}$ terceira etapa, 'o aumento do realismo, considerados os custos de transação', de acordo com os autores, acrescentam-se, como o nome indica, os custos de transação da implementação de tais regras. "A questão essencial nesta etapa é determinar se a regra que visa a controlar uma forma de custo de transação consegue, globalmente, reduzir os custos, dado o custo que ela mesma cria"77.

$\mathrm{Na}$ última etapa, 'estudos empíricos', são construídas hipóteses que reproduzam a realidade de forma que "a observação sistemática da realidade permita, então, pronunciar-se sobre o bom fundamento de nossas análises"78. Segundo os autores, essa etapa "exige o domínio de um conjunto de ferramentas especializadas (formulação de modelos, técnicas de análise de dados etc.)"79, sendo útil em todos os níveis da análise.

\footnotetext{
72 MACKAAY, Ejan; ROUSSEAU, Stéphane. Análise Econômica do Direito. trad. Rachel Sztajn. 2.ed. São Paulo: Atlas, 2015. p. 668.

73 MACKAAY, Ejan; ROUSSEAU, Stéphane. Análise Econômica do Direito. trad. Rachel Sztajn. 2.ed. São Paulo: Atlas, 2015. p. 669.

${ }^{74}$ MACKAAY, Ejan; ROUSSEAU, Stéphane. Análise Econômica do Direito. trad. Rachel Sztajn. 2.ed. São Paulo: Atlas, 2015. p. 669.

75 MACKAAY, Ejan; ROUSSEAU, Stéphane. Análise Econômica do Direito. trad. Rachel Sztajn. 2.ed. São Paulo: Atlas, 2015. p. 670.

${ }^{76}$ MACKAAY, Ejan; ROUSSEAU, Stéphane. Análise Econômica do Direito. trad. Rachel Sztajn. 2.ed. São Paulo: Atlas, 2015. p. 670.

77 MACKAAY, Ejan; ROUSSEAU, Stéphane. Análise Econômica do Direito. trad. Rachel Sztajn. 2.ed. São Paulo: Atlas, 2015. p. 672.

${ }^{78}$ MACKAAY, Ejan; ROUSSEAU, Stéphane. Análise Econômica do Direito. trad. Rachel Sztajn. 2.ed. São Paulo: Atlas, 2015. p. 673.

MACKAAY, Ejan; ROUSSEAU, Stéphane. Análise Econômica do Direito. trad. Rachel Sztajn. 2.ed. São Paulo: Atlas, 2015. p. 674.
} 
Esclarecida a forma como ocorre a análise, passar-se-á à tentativa de realização de uma breve análise das normas materiais relativas à DPJ.

O primeiro nível, de cálculo dos efeitos, é associado à primeira etapa, de estudo das estruturas de incentivos. Nesse sentido é possível afirmar que os sócios devem observar, principalmente, o artigo 50 do Código Civil, que determina que poderão ser desconsideradas as pessoas jurídicas que abusarem de sua condição. A lei pretende incentivar a atuação social sem abusos da Pessoa Jurídica e tem como efeito a desconsideração da Pessoa Jurídica que agir em desacordo com a lei e o consequente alcance do patrimônio dos sócios que assim o fizeram.

O segundo nível procura analisar os fundamentos da norma de forma a verificar se ela é eficiente, ou seja, se seus resultados causam efeitos no bem-estar geral capazes de atingir o critério de Kaldor-Hicks, de acordo com o qual as mudanças ocorram apenas quando os ganhadores puderem compensar os perdedores, conforme citado no item sobre a AED. Nesse nível pode ser utilizada a segunda etapa, procurando encontrar a regra cujos custos sejam mais baixos.

Quanto às regras sobre a DPJ, os critérios estabelecidos podem ser avaliados considerando-se o próprio patrimônio dos sócios, o quanto ganhariam agindo em desacordo com a lei, entre outros. Nessa etapa a avaliação torna-se mais casuística, devendo ocorrer segundo as informações do caso concreto.

Antes de partirmos ao terceiro nível, que também pode ser observado pela segunda etapa, observaremos a próxima etapa. Assim, a análise a partir da terceira etapa implica a consideração dos custos de transação envolvidos no caso concreto. Quanto à Desconsideração da Personalidade Jurídica, os custos podem dizer respeito à própria continuidade da empresa, aos prejuízos a sua imagem, ao risco que o patrimônio dos sócios corre, etc.

Além disso, a própria regra deve observar esses custos de transação ao ser criada, estabelecendo maiores ou menores ônus aos responsáveis. No caso do artigo 50 supracitado, por exemplo, do abuso da PJ apenas decorre sua desconsideração, sendo necessária a associação de outras normas para que aos culpados caibam punições que possam corresponder a custos tão altos que os impeçam de cometer esse tipo de crime, para o caso de a desconsideração não servir como obstáculo.

Por fim, a quarta etapa procura realizar estudos empíricos e está intimamente ligada ao terceiro nível de análise, que busca a norma desejável. Não pretende esta pesquisa criar modelos ou novas regras para a DPJ, mas avaliar as existentes sob a ótica da AED, portanto, nesta etapa é possível somente afirmar que as normas materiais que estabelecem critérios para 
a desconsideração de pessoas jurídicas indevidamente utilizadas precisam implicar em custos tão altos que impeçam, ou diminuam consideravelmente, a ocorrência desses casos.

No que diz respeito à Teoria Maior da DPJ, os impactos são relevantes, uma vez que o abuso é avaliado de forma a responsabilizar diretamente os agentes do ilícito. No entanto, quando analisamos a aplicação da Teoria Menor podemos perceber um desequilíbrio na eficiência da regra, que atinge indistintamente os sócios, sem utilização de critérios que apontem os verdadeiros culpados.

Nessa situação, os ganhadores não conseguem compensar os perdedores porque nem todos os sócios que perderam seu patrimônio o aumentaram por abuso, ocorrendo, nessa situação, um desequilíbrio. Ou seja, se quem paga não foi quem obteve lucro com o abuso da PJ, então este divide o prejuízo com quem lucrou; quem lucrou continua lucrando porque manteve parte do ganho ilícito e quem não tinha lucrado aumenta seu prejuízo.

Neste sentido, parece possível afirmar que a Teoria Menor aumenta os custos sociais, pois diminui o ônus do ilícito, além de prejudicar a própria Pessoa Jurídica que é posta em maior risco, prejudicando, assim, o bem-estar geral.

\section{CONCLUSÃO}

Do estudo inicial, ao explorar o tema da Análise Econômica do Direito, pode-se afirmar que é um método que analisa as normas postas, os custos por estas causados e os que elas pretendem amenizar, além de testar hipóteses para alteração da situação posta de maneira a alcançar um ponto de equilíbrio representado pelo bem-estar social.

Esse método, assim, se dispõe a alocar os poucos recursos disponíveis na sociedade da forma mais eficiente possível, mesmo diante das imperfeições do mercado, que são as externalidades, custos de transação causados pelas normas ou que precisam ser por elas amenizados por meio de incentivos.

O objetivo, portanto, da Análise Econômica do Direito não é estabelecer novas normas, mas avaliar as que estão postas e demonstrar sua eficiência ou não pela comparação com outras possíveis no caso que estiver em estudo.

Nesta pesquisa, o instituto da Desconsideração da Personalidade Jurídica foi relacionado à AED no intuito de avaliação das estruturas de incentivos e, assim, da análise da eficiência das normas materiais que tratam do assunto. 
Diante do estudo, afirma-se que a Pessoa Jurídica é uma ficção capaz de adquirir direitos e contrair obrigações; e que sua desconsideração pode ocorrer quando a PJ é utilizada para cometer abusos. Tal desconsideração implica o rompimento com a ideia de limitação de patrimônio do sócio ao limite do capital integralizado ou investido, tornando-o alvo de execuções decorrentes da atuação societária.

Pode-se afirmar, também, que o desenvolvimento deste instituto, no Brasil, tem como marco inicial o ano de 1969, quando Rubens Requião tratou pela primeira vez do tema em uma conferência universitária; e que as teorias desse instituto têm como bases doutrinárias, principalmente, a doutrina alemã, com Rolf Serick, e a italiana, de Pierro Verrucoli.

As bases materiais deste instituto são o artigo $28, \$ 5^{\circ}$ do Código de Defesa do Consumidor e o artigo 50 do Código Civil, principalmente, uma vez que representam as teorias acerca do tema; são elas a Teoria Maior da Desconsideração da Personalidade Jurídica, que estabelece requisitos para que a Pessoa Jurídica seja desconsiderada, e a Teoria Menor, que desconsidera a PJ sempre que ela seja obstáculo ao ressarcimento de prejuízos causados pela Pessoa Jurídica.

Ao analisar esse instituto sob a luz da AED pode-se concluir que existem diferenças na aplicação da DPJ de acordo com a teoria utilizada. Isto ocorre porque existem incentivos diversos para as duas teorias. Enquanto na Teoria Maior apenas o sócio que deu causa ao abuso é responsabilizado e tem seu patrimônio atingido, na Teoria Menor os sócios são atingidos mesmo que não tenham cometido nenhum ato ilícito.

As consequências dessas diferenças estão nos incentivos da norma para que os abusos aconteçam em maior ou menor número. Nos casos em que os sócios culpados arcam com as consequências de seus atos, a sensação é de justiça, desonerando os sócios que agiram nos rigores da lei, proporcionando o aumento do bem-estar social. Já nos casos em que ou os sócios não tiveram culpa ou todos responderam pela atitude de alguns, o sentimento é de injustiça, causando maiores custos ao mercado, posto que os sócios que pagaram pelo abuso de outros passam a ter incentivo negativo, considerando que não 'vale a pena' agir corretamente.

Conclui-se, assim, que à luz da Análise Econômica do Direito a aplicação da Teoria Maior da Desconsideração da Personalidade Jurídica é eficiente, ao contrário do que ocorre com a Teoria Menor, que é ineficiente por aumentar os custos a que os sócios estão sujeitos. 


\section{REFERÊNCIAS}

ALVAREZ, Alejandro Bugallo. Análise Econômica do Direito: Contribuições e desmistificações. Direito, Estado e Sociedade, Rio de Janeiro-RJ, v. 9, n. 29, p. 49-68, jul./dez. 2006.

BASTOS, Luciana de Castro. A Desconsideração da Personalidade Jurídica e a Empresa Familiar. Porto Alegre, RS: Editora Fi, 2019.

BITTENCOURT, Maurício Vaz Lobo. Princípio da Eficiência. In: RIBEIRO, Márcia Carla Pereira; KLEIN, Vinícius (Coord.) $O$ que é análise econômica do direito: uma introdução. Belo Horizonte: Fórum, 2011.

BRASIL, Lei 1.305 de 16 de março de 2015. Código de Processo Civil: anteprojeto / comissão de Juristas Responsável pela elaboração de Anteprojeto de Código Civil. Brasília: Senado Federal, Presidência, 2010.

COELHO, Fábio Ulhoa. Desconsideração da Personalidade Jurídica. São Paulo: Revista dos Tribunais, 1989.

COMPARATO, Fábio Konder. 0 poder de controle na sociedade anônima. São Paulo: Revista dos Tribunais, 1977.

DOMINGUES, Vitor Hugo. Ótimo de Pareto. In: RIBEIRO, Márcia Carla Pereira; KLEIN, Vinícius (Coord.) $O$ que é análise econômica do direito: uma introdução. Belo Horizonte: Fórum, 2011.

FARIAS, Cristiano Chaves de; ROSENVALD, Nelson. Curso de Direito Civil: Parte Geral e LINDB. São Paulo: Editora Atlas S.A., 2015.

GICO JR., Ivo T.. Introdução à Análise Econômica do Direito. In: RIBEIRO, Márcia Carla Pereira; KLEIN, Vinícius (Coord.) $O$ que é análise econômica do direito: uma introdução. Belo Horizonte: Fórum, 2011.

GICO JR., Ivo T.. Introdução ao Direito e Econômica. In: TIMM, Luciano Benetti (Org.) Direito e Economia no Brasil. São Paulo: Atlas, 2014

KOURY, Suzy Elizabeth Cavalcante. A desconsideração da personalidade jurídica (disregard doctrine) e os grupos de empresas. 4. ed. São Paulo: LTr, 2018

LOPES, Herton Castiglioni. Instituições e crescimento econômico: os modelos teóricos de Thorstein Veblen e Douglass North. Revista de Economia Política, v. 33, n. 4, p. 619-637, 2013.

MACKAAY, Ejan; ROUSSEAU, Stéphane. Análise Econômica do Direito. Trad. Rachel Sztajn. 2. ed. São Paulo: Atlas, 2015.

NORTH, Douglass C. The new institutional economics and third world development. In: The new institutional economics and third world development. Routledge, 2003. p. 31-40. 
OLIVEIRA, José Lamartine Correia de. A dupla crise da pessoa jurídica. São Paulo: Saraiva, 1979.

PORTO, Antônio José Maristrello. Análise Econômica do Direito (AED). Rio de Janeiro: Fundação Getúlio Vargas, 2013.

REQUIÃO, Rubens. Abuso de Direito e fraude através da personalidade jurídica. Revista dos Tribunais. São Paulo, v. 410, ano 58, p. 12-24, dezembro, 1969.

RIBEIRO, Márcia Carla Pereira. Racionalidade Limitada. In: RIBEIRO, Márcia Carla Pereira; KLEIN, Vinícius (Coord.) $O$ que é análise econômica do direito: uma introdução. Belo Horizonte:

Fórum, 2011.

SALAMA, Bruno Meyerhof. A História do Declínio e Queda do Eficientismo na Obra de Richard Posner. In: LIMA, Maria Lúcia L. M. Pádua (org.). Trinta Anos de Brasil: Diálogos entre Direito e Economia. São Paulo: Saraiva, 2012. Republicado: Revista do Instituto do Direito Brasileiro da Faculdade de Direito da Universidade de Lisboa (RIDB), n. 1, 2012. Disponível em: https://works.bepress.com/bruno_meyerhof_salama/35. Acesso em 01 nov. 2019.

SOUZA, André Pagani de. Desconsideração da personalidade jurídica: aspectos processuais. 2. ed., São Paulo: Saraiva, 2011, E-book.

SZTAJN, Rachel. Law and Economics. In: ZYLBERSZTAJN, Decio; SZTAJN, Rachel (Org.). Direito \& Economia: Análise Econômica do Direito e das Organizações. São Paulo: Elsevier Editora Ltda., 2005.

TALAMINI, Eduardo. Incidente de desconsideração da personalidade jurídica. Migalhas. 02 de março de 2016. Disponível em: http: / /www.migalhas.com.br/dePeso/16,Ml234997,11049Incidente+de+desconsideracao+de+personalidade+juridica. Acesso em: 01 nov. 2019.

TARTUCE, Flávio. A Desconsideração da Personalidade Jurídica e suas aplicações ao Direito de Família e das Sucessões. Migalhas, 25 de outubro de 2017. Disponível em:

https: //www.migalhas.com.br/FamiliaeSucessoes/104,MI267804,51045-

A+desconsideracao+da+personalidade+juridica+e+suas+aplicacoes+ao. Acesso em: 01 nov. 2019.

TOMAZETTE, Marlon. Curso de Direito Empresarial: Teoria Geral e Direito Societário. 8. ed., São Paulo: Atlas, 2017, 1. v.

WILLIAMSON, Oliver E. Custos de Transação Econômicos: a governança dos Contratos Relacionais. Jornal de Direito e Economia, v. 22, n. 2, p. 233-261, 1979. 


\section{COMO FAZER REFERÊNCIA AO ARTIGO (ABNT):}

BARELLA, Ana Lúcia; GIBRAN, Sandro Mansur. A desconsideração da personalidade jurídica sob a ótica da análise econômica do direito. Revista Eletrônica do Curso de Direito da UFSM, Santa Maria, RS, v. 15, n. 1, e31736, jan./abr. 2020. ISSN 1981-3694. DOI: http://dx.doi.org/10.5902/1981369431736. Disponível em: https://periodicos.ufsm.br/revistadireito/article/view/31736 Acesso em: dia mês. ano.

Direitos autorais 2020 Revista Eletrônica do Curso de Direito da UFSM

Editores responsáveis: Rafael Santos de Oliveira e Angela Araujo da Silveira Espindola

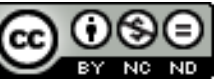

Esta obra está licenciada com uma Licença Creative Commons Atribuição-NãoComercial-SemDerivações 4.0 Internacional.

\section{SOBRE OS/AS AUTORES/AS}

\section{ANA LÚCIA BARELLA}

Mestranda no Programa em Direito Empresarial e Cidadania pelo Centro Universitário Curitiba - UNICURITIBA (bolsista). Pósgraduanda (especialização) em Direito Educacional. Atua na assessoria jurídica da Secretaria Municipal de Educação de São José dos Pinhais, funcionária pública neste município. Experiência na área do magistério com Ensino Fundamental em escolas públicas municipais desde 2002. Co-fundadora, autora, avaliadora e Membro da Diretoria do portal jurídico Novo Jurista. Participa do grupo de estudos em Direito Empresarial, desde o início de 2017, no Centro Universitário Curitiba - UNICURITIBA, sob orientação do prof. Dr. Sandro Mansur Gibran. Graduada em Direito pelo Centro Universitário Curitiba - UNICURITIBA (2017), monitora em Direito do Consumidor (2016), desenvolveu monografia em Direito Empresarial: O INCIDENTE DE DESCONSIDERAÇÃO DA PERSONALIDADE JURÍDICA NO NCPC E SUA APLICABILIDADE NOS JUIZADOS ESPECIAIS CÍVEIS SOb orientação do prof. Me Leonel Vinícius Jaeger Betti Junior. Pós-graduada (especialista) em Literatura Brasileira e Ensino de Língua Portuguesa na UTFPR - Universidade Tecnológica Federal do Paraná (2007). Graduada em Letras Portuguesa pela UFPR - Universidade Federal do Paraná (2005). Magistério (1999) - Colégio Estadual Cianorte, Cianorte/PR.

\section{SANDRO MANSUR GIBRAN}

Doutor em Direito Econômico e Socioambiental pela Pontifícia Universidade Católica do Paraná (2009). Mestre em Direito Social e Econômico pela Pontifícia Universidade Católica do Paraná (2003). Graduado em Direito pela Faculdade de Direito de Curitiba (1996). É advogado. Professor de Direito Empresarial junto ao Centro de Estudos Jurídicos do Paraná ? CEJPR e na Escola da Magistratura Federal do Paraná ? ESMAFE/PR. Professor visitante na Universidade da Indústria da Federação das Indústrias do Estado do Paraná ? UNINDUS. Coordenador do Curso de Pós-Graduação em Direito Empresarial do UNICURITIBA. Coordenador do Curso de Pós-Graduação em Direito Contratual do UNICURITIBA. Professor permanente no Programa de Mestrado e Doutorado em Direito Empresarial e Cidadania do UNICURITIBA. Realizou estágio Pós-Doutoral na Universidade Federal do Paraná (2015/2017). Tem experiência em: Direito Empresarial Societário. Função Social da Atividade Empresarial. Negócios Empresariais. Consumo Consciente e Sustentável. 